\title{
USULAN PERBAIKAN DEFECT PADA SABLON PLASTIK MENGGUNAKAN METODE POKA YOKE DI CV. BAYOR PRINT 69
}

\author{
Novita Yanti Nababan ${ }^{1}$, Achmad Faizal ${ }^{2}$, M. Edgar Jatnika ${ }^{3}$ \\ Fakultas Teknik ${ }^{1,2,3}$ \\ Universitas Widyatama \\ Jl. Cikutra No.204A, Bandung \\ $\underline{\text { novita.yanti@widyatama.ac.id }{ }^{1} \text { achmad.faizal62@gmail.com }{ }^{2}} \underline{\text { Muhamadedgar00@gmail.com }}{ }^{3}$
}

\begin{abstract}
Abstrak
Kunci utama perusahaan dapat bertahan dan bersaing pada era MEA adalah dengan berfokus pada kualitas, baik kualitas produk maupun kualitas dalam proses produksinya. Perbaikan kualitas menjadi perhatian utama bagi perusahaan. Perbaikan kualitas membuat produk cacat (defect) dapat ditekan seminimal mungkin hingga mencapai produk cacat nol (zero defect). Penelitian ini bertujuan untuk mengetahui kualitas dari produk Sablon Plastik, menganalisis jenis kecacatan produk dan kecacatan pada proses produksinya, kecacatan produk prioritas, akar penyebab kecacatan, dan pemberian usulan perbaikannya di CV. BAYOR PRINT 69. Penelitian ini menggunakan data primer yang diperoleh dari wawancara langsung bersama informan-informan terkait dan menggunakan data sekunder berupa data produksi dan data cacat Sablon Plastik CV. BAYOR PRINT 69 pada bulan Januari-Desember 2018. Informan didalam penelitian ini terdiri dari karyawan yang bekerja pada CV. BAYOR PRINT 69. Penelitian ini dianalisis menggunakan diagram pareto, diagram tulang ikan, dan teknik brainstorming. Dari hasil analisis, dapat disimpulkan bahwa: (1) kualitas produk Sablon Plastik tergolong baik, (2) cacat terbanyak terdapat pada kelompok cacat A1, yaitu cat yang meleber pada plastik, (3) manusia merupakan faktor penyebab cacat terbanyak, (4) solusi perbaikan yang dapat diterapkan adalah mengaplikasikan ketiga fungsi dari metode poka yoke, yaitu warning, control, dan shut down, serta penambahan operator mesin.
\end{abstract}

Kata kunci:

Poka yoke, six sigma, zero defect

\begin{abstract}
The main key for a company to survive and compete in the MEA era is to focus on quality, both product quality and quality in the production process. Quality improvement is a major concern for the company. Quality improvements make the defect product can be reduced to a minimum until it reaches zero defect. This study aims to determine the quality of Plastic Screen Printing products, analyze the types of product defects and defects in the production process, priority product defects, the root causes of disabilities, and the proposed improvement in CV. BAYOR PRINT 69. This study uses primary data obtained from direct interviews with relevant informants and uses secondary data in the form of production data and Plastic Screening defect data CV. BAYOR PRINT 69 in January-December 2018. The informants in this study consisted of employees who worked at CV. BAYOR PRINT 69. This study was analyzed using Pareto diagrams, fish bone diagrams, and brainstorming techniques. From the results of the analysis, it can be concluded that: (1) the quality of Plastic Screen Printing products is relatively good, (2) the most defects are found in the Al defect group, namely the paint which is melted on the plastic, (3) humans are the factors causing the most defects, (4) the solution improvement that can be applied is to apply the three functions of the poka yoke method, namely warning, control, and shut down, as well as the addition of the machine operator
\end{abstract}

Keywords:

Poka yoke, six sigma, zero defect

\section{Pendahuluan}

Kualitas memang tidak terlepas dari manajemen kualitas yang mempelajari setiap area dari manajemen operasi dari perencanaan lini produk dan fasilitas. 
Kualitas merupakan bagian dari semua fungsi usaha yang lain (pemasaran, sumber daya manusia, keuangan, dan lain-lain). Kualitas produk meliputi kualitas bahan baku dan barang jadi, sedangkan kualitas proses meliputi kualitas segala sesuatu yang berhubungan dengan proses produksi perusahaan manufaktur dan proses penyediaan jasa atau pelayanan bagi perusahaan jasa. Masalah persaingan perusahaan di Indonesia kini kian ketat seiring dengan terbentuknya MEA (Masyarakat Ekonomi ASEAN), sehingga perusahaan harus terus melakukan berbagai cara agar mampu bertahan dan bersaing. Salah satu strategi bersaing yang dapat diterapkan perusahaan adalah dengan fokus pada kualitas, khususnya kualitas produk, jika perusahaan tersebut dapat menghasilkan suatu produk yang memiliki mutu tinggi dan harga bersaing, maka perusahaan tersebut cenderung akan menguasai pasar dan dapat bersaing dalam persaingan bisnis yang semakin ketat. Perusahaan-perusahaan di Indonesia saat ini mengalami persaingan yang ketat baik dari produser luar negeri, maupun dari usahausaha kecil di Indonesia yang makin banyak timbul dan makin berkembang. Persaingan ini menyebabkan perusahaan yang sudah ada sekarang harus memiliki keunggulan bersaing yang tinggi. Keunggulan bersaing dapat diperoleh dengan cara menurunkan harga, meningkatkan kualitas, dan memperpendek waktu yang dibutuhkan konsumen antara pemesanan sampai pengiriman. Perusahaan saat ini menyadari bahwa mereka memiliki persentase cacat yang cukup banyak, yang menyebabkan banyak komplain dari konsumen dan biaya produksi membesar karena harus menutup biaya rework dan scrap yang menyebabkan marjin profit berkurang.

Upaya yang dilakukan sekarang adalah dengan banyaknya pemeriksaan kualitas, tetapi dengan upaya ini waktu produksi jadi meningkat, biaya cukup mahal untuk tenaga kerja pemeriksa kualitas, produk cacat tetap banyak, hanya tidak sampai ke tangan konsumen, sehingga biaya produksi mahal (banyak scrap dan rework). Salah satu perusahaan yang ingin berfokus pada kualitas adalah perusahaan konveksi pembuatan kantong plastik yaitu CV. BAYOR PRINT 69. Salah satu produk andalan perusahaan ini adalah Sablon Plastik. Dalam berproduksi, perusahaan memiliki salah satu tujuan utama yaitu produksi dengan tidak ada kecacatan atau cacat nol (zero defect). Namun, dalam menjalankan proses produksinya, perusahaan masih saja menemui kendala, khususnya kendala yang dapat menimbulkan cacat pada kualitas produksi. Berikut data persentase cacat Sablon Plastik selama periode Januari sampai dengan Desember 2018 CV. BAYOR PRINT 69.

Tabel 1 Produksi dan Cacat Sablon Plastik CV.BAYOR PRINT 69 Januari s.d. Desember 2018

\begin{tabular}{|c|c|c|c|c|c|}
\hline \multicolumn{7}{|c|}{ Produksi dan Cacat Sablon Plastik CV. BAYOR PRINT 69 } \\
\hline Bulan & Produksi (pcs) & Cacat (pcs) A1 & Cacat (pes) A2 & Presentase Cacat A1 & Presentase Cacat A2 \\
\hline Januari & 1800 & 34 & 8 & $1,89 \%$ & $0,44 \%$ \\
\hline Februani & 2600 & 56 & 12 & $2,15 \%$ & $0,46 \%$ \\
\hline Maret & 2400 & 44 & 11 & $1,83 \%$ & $0,46 \%$ \\
\hline April & 5500 & 58 & 17 & $1,05 \%$ & $0,31 \%$ \\
\hline Mei & 5200 & 61 & 19 & $1,17 \%$ & $0,37 \%$ \\
\hline Jumi & 5800 & 63 & 16 & $1,09 \%$ & $0,28 \%$ \\
\hline Juli & 5400 & 59 & 14 & $1,09 \%$ & $0,26 \%$ \\
\hline Agustus & 1400 & 18 & 5 & $1,29 \%$ & $0,36 \%$ \\
\hline September & 1600 & 23 & 2 & $1,44 \%$ & $0,13 \%$ \\
\hline Oktober & 1200 & 11 & 3 & $0,92 \%$ & $0,25 \%$ \\
\hline November & 1100 & 12 & 9 & $1,09 \%$ & $0,82 \%$ \\
\hline Desember & 1500 & 15 & 6 & $1,00 \%$ & $0,40 \%$ \\
\hline
\end{tabular}

*Batas toleransi kecacatan adalah 1,5\% (CV. BAYOR PRINT 69) Sumber: CV. BAYOR PRINT 69

Produk sablon plastik memiliki dua jenis cacat produk, yaitu A1 dan A2. A1 yaitu cacat yang dikarenakan cat yang meleber sedangkan untuk A2 yaitu cacat yang dikarenakan plastik yang digunakan mengalami kerusakan. Cacat terbanyak pada produk sablon plastik terdapat pada cacat produk sablon plastik dengan jenis cacat A1. Berdasarkan data perusahaan diatas dapat diketahui bahwa terdapat beberapa jumlah produk cacat masih melebihi batas toleransi kecacatan yang telah ditetapkan oleh perusahaan dengan besaran batas toleransi sebesar $1,5 \%$. Selain itu, produk Sablon Plastik juga belum memenuhi tujuan produksi perusahaan, yaitu belum mencapai cacat nol dalam berproduksi. Berdasarkan tabel di atas, dapat diketahui pula bahwa total produksi dan total cacat produk Sablon Plastik per bulan pada periode bulan Januari-Desember 2018 mengalami fluktuasi. Hal tersebut kemungkinan dapat disebabkan oleh beberapa faktor, seperti adanya faktor kelalaian dari tenaga kerja, faktor kerusakan pada mesin, metode pengoperasian yang digunakan salah, dan bahan baku yang digunakan tidak sesuai dengan standar yang ditetapkan.

Dengan kondisi ini perusahaan harus
memperbaiki kualitas dengan memperbaiki
pengendalian kualitas dan pengendalian proses,
dengan pengendalian kualitas dan pengendalian
proses yang lebih baik, diharapkan perusahaan dapat
memperbaiki kualitas produknya yang akan
meningkatkan penjualan, menurunkan biaya kualitas
dan meningkatkan marjin profit, untuk mendapatkan
produk bermutu, perusahaan dapat menerapkan sistem
manajemen mutu yang menggunakan ide perbaikan
terus menerus dengan menggunakan tools dan quality
method yang ada, dan dengan menggunakan proses


daur ulang teknologi yang ada di dalam proses produksi (Burlikowska, 2009).

Adapun tujuan dari penelitian ini adalah (1) Untuk mengidentifikasi penyebab terjadinya defect produk yang dihasilkan pada proses produksi. (2) Untuk memberikan usulan perbaikan terhadap defect yang dihasilkan dengan menggunakan metode poka yoke.

\section{KAJIAN LITERATUR}

\section{Proses Produksi}

Menurut Assauri (2016) proses produksi merupakan suatu kegiatan yang melibatkan tenaga manusia, bahan serta peralatan untuk menghasilkan produk yang berguna. Proses produksi merupakan proses pengubahan (transformasi) dari bahan atau komponen (input) menjadi produk lain yang mempunyai nilai lebih tinggi atau dalam proses terjadi penambahan nilai (Zulian, 2013). Berdasarkan penjelasan tersebut, maka proses produksi dapat didefinisikan pula sebagai suatu kegiatan atau teknik yang digunakan sebagai pengelolaan suatu input yang kemudian diproses menjadi output.

\section{Kualitas}

Menurut Murdifin dan Mahfud (2014), Kualitas atau mutu memiliki berbagai macam definisi atau makna, antara lain, mutu adalah keistimewaan produk yang dapat menjawab kebutuhan kocnsumen, mutu adalah sesuatu yang bebas dari cacat atau zero defect, dan mutu adalah kesesuaian dengan tujuan pengguna. Secara khusus, kualitas dapat dipengaruhi oleh beberapa faktor, seperti proses produksi yang merupakan prosedur dalam memproduksi suatu produk, kualitas input seperti bahan baku dan tenaga kerja, perawatan perlengkapan yang benar dan tersedianya suku cadang, dan standar kualitas yang menjadi acuan bagi perusahaan dalam menghasilkan suatu produk (Zulian, 2013).

\section{Lean Manufacturing}

Demi mencapai produk yang bermutu, maka suatu organisasi dapat menerapkan sistem manajemen mutu yang menggunakan ide perbaikan terus menerus dengan menggunakan tools dan quality method yang ada, dan dengan menggunakan proses daur ulang teknologi yang ada di dalam proses produksi (Burlikowska, 2009). Lean manufacturing sering dikaitkan dengan pembuangan tujuh waste besar yang berfungsi dalam mengurangi dampak dari variabilitas pasokan, waktu pemrosesan atau penerimaan. Salah satu waste besar adalah cacat (defect). Gaspersz (2007), mengemukakan bahwa Lean manufacturing adalah suatu upaya terus menerus dalam menghilangkan waste dan meningkatkan nilai tambah produk berupa barang atau jasa agar dapat memberikan nilai kepada pelanggan.

\section{Waste Defect dan Zero defect}

Menurut Gaspersz dan Fontana, waste defect berarti pengerjaan ulang terhadap produk atau bahkan harus dimusnahkan. Defect sendiri dapat didefinisikan sebagai produk yang tidak sesuai dengan spesifikasinya. Sedangkan Halpin et al (1966) dalam Khrisnan (2015) mendefinisikan zero defect sebagai alat manajemen yang ditujukan untuk mengurangi cacat melalui pencegahan. Hal ini diarahkan untuk memotivasi orang untuk mencegah kesalahan dengan mengembangkan keinginan yang konstan dan sadar untuk melakukan pekerjaan mereka dengan benar pertama kali. Konsep dari zero defect adalah memastikan bahwa semua cacat yang ada dalam proses dihilangkan pada langkah pertama. Dengan begitu, zero defect digunakan untuk dijadikan acuan dalam meningkatkan kualitas yang mengarah pada kepuasan pelanggan (Khrisnan, 2015)

\section{Diagram Sebab Akibat}

Diagram sebab akibat (Cause and Effect Diagram) atau yang biasa disebut dengan diagram tulang ikan (Fishbone Diagram) merupakan salah satu alat yang mengidentifikasikan elemen proses (penyebab) yang mungkin mempengaruhi hasil (Heizer dan Render, 2015).

\section{Diagram Pareto Diagram}

Pareto (Pareto Chart) digunakan untuk membandingkan berbagai kategori kejadian yang disusun menurut ukurannya, dari yang paling besar terletak di sebelah kiri ke yang paling kecil di sebelah kanan (Nasution, 2010). Sedangkan menurut Heizer dan Rander (2015), diagram Pareto merupakan sebuah metode untuk mengelola kesalahan masalah, atau cacat untuk membantu memusatkan perhatian pada usaha penyelesaian masalah.

\section{Poka Yoke}

Poka yoke berasal dari bahasa jepang yang artinya adalah mencegah kesalahan yang dikarenakan oleh kecerobohan oleh tenaga manusia. Menurut konsep poka yoke pada dasarnya sifat manusia adalah 
pelupa dan cenderung untuk berbuat salah, apalagi yang sering terjadi ditempat kerja, pekerjalah yang sering disalahkan (Dave, 2015). Hal ini bukan saja dapat mematahkan semangat kerja karyawan tetapi juga tidak dapat menyelesaikan masalah yang terjadi. Oleh karena itu, metode Poka Yoke menjadi sangat penting dalam menghindari kesalahan yang terjadi. Di dalam kegiatan produksi atau kerja banyak faktor yang menyebabkan defect akibat kesalahan kerja, di antaranya faktor manusia, material, mesin, metode, informasi, dan lain-lain, namun jika ditelusuri kita akan sampai pada suatu fakta bahwa setiap defect sumbernya adalah manusia. Sangat fatal jika sikap kita dengan mengatakan, "Ya, tidak ada yang dapat diperbuat terhadap sebuah kasalahan, manusia selalu membuat kesalahan". dan sayangnya kita cenderung menerima kasalahan sebagai hal yang biasa, dan menyalahkan orang yang membuat kesalahan. dengan sikap seperti ini, kita mungkin sama saja dengan membiarkan defect terjadi dalam Produksi, Akhirnya defect ini terdeteksi hanya pada saat inspeksi terakhir atau, yang lebih parah, terdeteksi oleh Pelanggan. Seharusnya kita memiliki sikap, bahwa kesalahan dapat dikurangi atau bahkan dihilangkan. Salah satu caranya mengurangi atau menghilangkan kesalahan yang bersumber pada manusia atau human error adalah dengan Poka Yoke. Poka Yoke berasal dari bahasa Jepang yokeru yang berarti "menghindari" dan poka yang berarti "kesalahan (diakibatkan kelalaian dan/atau ketidaksengajaan)". Jadi secara sederhana Poka Yoke adalah menghindari kesalahan dalam produksi atau kerja. Konsep Poka Yoke ditemukan oleh Shigeo Shingo, seorang insinyur di Matsushita manufacturing dan merupakan bagian dari Toyota Production System. Poka Yoke awalnya disebut sebagai Baka Yoke, namun karena artinya kurang pantas, yaitu "menghindari ketololan", maka kemudian diubah menjadi Poka Yoke. Secara umum, Poka Yoke didefinisikan sebagai suatu konsep manajemen mutu guna menghindari kesalahan akibat kelalaian dengan cara memberikan batasan-batasan dalam pengoperasian suatu alat atau produk dan pada umumnya berkaitan dengan isu produk cacat atau defects. Shigeo Shingo memperkenalkan 3 jenis Poka Yoke (Aishwarya, 2015):

a. Metode Kontak, mengidentifikasi apakah ada kontak antara alat dan produk.

b. Metode Nilai-Tetap, memastikan apakah sejumlah tertentu gerakan telah dilakukan.
Metode Tahap-Gerak, memastikan apakah sejumlah langkah proses tertentu telah dilakukan.

Poka Yoke berfungsi optimal saat ia mencegah terjadinya kesalahan, bukan pada penemuan adanya kesalahan. Karena kelalaian operator atau pekerja biasanya terjadi akibat letih, ragu-ragu atau bosan atau jenuh. Jadi Poka Yoke mencegah terjadinya kesalahan atau kerusakan atau defect yang bisa terjadi akibat human error. Keberadaan Poka Yoke menjadi sangat berarti karena solusi mencegah terjadinya kelalaian tersebut sama sekali tidak memerlukan perhatian penuh dari operator bahkan saat si operator sedang tidak fokus dengan apa yang dikerjakannya. Penerapan konsep Poka Yoke dalam kehidupan sehari-hari pun ternyata sangat banyak ditemukan. Contoh paling umum adalah kesalahan pemasangan akan dideteksi dan pemakai seolah "diingatkan" kalau telah terdapat kekeliruan/pemasangan yang tidak tepat atau terbalik. Poka Yoke (poh-ka yoh-ke) merupakan strategi dan kebijaksanaan untuk mencegah defect di dalam sumbernya dengan cara melakukan inspeksi secara terus menerus demi mencapai zero defect product. Namun, pada dasarnya metode poka yoke juga merupakan salah satu metode yang tepat dapat mencegah cacat yang diakibatkan oleh kesalahan manusia dalam bekerja (Burlikowska, 2009). Terdapat tiga fungsi dasar Poka Yoke dalam menjalankan tugasnya dalam mencegah cacat, yaitu warning yang berfungsi sebagai pengingat dan pemberi peringatan kepada petugas jika terjadi kesalahan, yaitu dengan memberikan sinyal baik berupa suara, lampu yang menyala dan sinyal lainnya, control yake berperan sebagai suatu metode kontrol yang berfungsi dalam mengontrol dan mendeteksi jalur atau proses produksi yang dapat menimbulkan masalah, dan shut down yang berupa suatu metode pencegahan perangkat poka- yoke dengan cara memeriksa parameter proses kritis dan menutup atau menghentikan proses saat proses tersebut tidak dapat ditoleransi.

Berikut Langkah-langkah persiapan penerapan Poka Yoke, yaitu (Praktik, 2015):

1. Deskripsikan kerusakan atau potensi kerusakan yang akan diselesaikan. Buat Ratio atau persentasi kerusakan yangterjadi.

2. Identifikasi proses mana yang terjadi kerusakan tersebut.

3. Tuliskan secara jelas dan rinci langkah kerja pada proses yang akan di analisis.

Novita Yanti Nababan, Achmad Faizal, M. Edgar Jatnika 
4. Perhatikan dengan seksama proses tersebut. Apakah ada perbedaan dengan apa yang telah dirinci.

5. Langkah kerja ataupun kondisi yang dapat menyebabkan kerusakan/kesalahan kerja seperti lingkungan, alat pengukur dan peralatan kerja. pergunakanlah metode penyelesaian masalah 5 WHY (5 Mengapa) untuk mendapatkan akar faktor penyebabnya.

6. Identifikasi peralatan Poka Yoke yang akan dipakai untuk menyelesaikan permasalahan tersebut

7. Lakukan evaluasi ulang setelah penerapan peralatan Poka Yoke

Metodologi poka yoke terdiri dari Identify Problem, yang merupakan langkah awal dalam mengidentifikasi permasalahan dengan melakukan identifikasi proses yang berpotensi dalam menimbulkan permasalahan. Observation at Workstation, merupakan langkah setelah mengetahui sumber masalah dan masalah apa saja yang terjadi menggunakan diagram tulang ikan. Brainstorming for Idea, dilakukan dengan cara mengajukan masalah yang diteliti kepada pihak internal perusahaan yang terkait, kemudian mempelajari masalah tersebut dan setelahnya akan dicari rencana dan solusi perbaikan menggunakan kreatifitas pemikiran yang ada oleh beberapa pihak internal perusahaan yang berkaitan tersebut. Select Best Idea, setelah mendapatkan beberapa alternatif solusi oleh beberapa pihak internal perusahaan yang terkait, langkah selanjutnya adalah dengan memilih solusi terbaik dari semua solusi yang terkumpul. Implementation Plan and Implementation, pada tahap ini perusahaan mulai mengimplementasikan solusi terbaik yang didapat melalui perundingan yang telah dilakukan sebelumnya. Monitoring and Sign Off, merupakan langkah terakhir, langkah dimana saatnya perusahaan memonitor setiap proses produksi menggunakan perbaikan yang telah ditetapkan (Kumar, et al, 2016).

\section{AnAlisis dan PeMbahasan}

\section{Definisi Operasional}

Definisi operasional dari penelitian ini meliputi hal-hal berikut:

1. Kualitas, yang dimaksud adalah berupa mutu yang bebas dari defect (zero defect), dimana nantinya dengan tercapainya cacat nol, maka akan membuat perusahaan mudah bersaing dengan perusahaan lain.

2. Zero Defect, didefinisikan sebagai tujuan dari perusahaan untuk mendapatkan kualitas terbaik, sehingga perusahaan mampu untuk bersaing di dalam persaingan yang semakin ketat.

3. Metode Poka Yoke, merupakan alat untuk menghilangkan cacat (zero defect), dimana dalam metode poka yoke akan dianalisis mengenai permasalahan prioritas yang dapat menyebabkan cacat dan menarik akar permasalahan tersebut menggunakan diagram tulang ikan, serta untuk solusinya akan menggunakan teknik brainstorming bersama beberapa pihak yang terkait.

Pendekatan Penelitian Pendekatan yang digunakan di dalam penelitian ini adalah pendekatan kualitatif dengan metode studi kasus deskriptif.

\section{Informan Penelitian}

Penelitian ini menggunakan informan sebagai berikut:

1. Informan kunci, yaitu orang yang mengetahui dan memiliki berbagai informasi pokok yang diperlukan dalam penelitian. Dalam hal ini Kasi produksi II menjadi informan kunci.

2. Informan utama, yaitu orang yang terlibat secara langsung dalam proses produksi. Operator mesin menjadi informan utama.

3. Informan tambahan, yaitu orang yang dapat memberikan informasi meskipun tidak langsung terlibat dalam hal yang diteliti. Dalam hal ini bagian quality control yaitu Kepala Regu Penelitian dan Pengembangan (Karu Litbang), bagian regu pemeliharaan dan Kepala Regu produk jadi CV. BAYOR PRINT 69 yang menjadi informan tambahan. Informan dalam penelitian ini ditentukan dengan purposive sampling.

\section{Teknik Pengumpulan}

Data Pengumpulan data dalam penelitian ini dilakukan dengan beberapa teknik sebagai berikut:

1. Observasi, pengamatan langsung terhadap permasalahan yang akan diteliti. Observasi dilakukan untuk mengetahui proses yang terjadi pada perusahaan (proses produksi). 
2. Wawancara, melakukan tanya jawab secara langsung dengan pihak internal perusahaan yang terkait dengan permasalahan untuk memperoleh datadata yang dibutuhkan dalam penelitian ini.

3. Dokumentasi, didapat dari beberapa laporan dan data internal perusahaan yang digunakan untuk menganalisis permasalahan.

\section{Jenis dan Sumber Data}

Jenis dan sumber data yang digunakan adalah sebagai berikut:

1. Data Primer, berupa penjelasan secara langsung dari pihak internal perusahaan secara lisan melalui proses wawancara

2. Data Sekunder, berupa data pelengkap berupa tulisan seperti data produksi dan data cacat

\section{Keabsahan Data}

Keabsahan data pada penelitian ini menggunakan teknik triangulasi, dimana teknik triangulasi ini merupakan teknik pemeriksaan keabsahan data yang memanfaatkan sesuatu yang lain dalam membandingkan hasil wawancara terhadap objek penelitian (Moleong, 2004 dalam Azis, 2015).

\section{Teknik Analisis Data}

Teknik analisis data menggunakan beberapa teknik sebagai berikut:

1. Penggunaan diagram pareto untuk mengetahui cacat prioritas Sablon Plastik berdasarkan data produksi dan data cacat Sablon Plastik pada bulan Januari-Desember 2018

2. Penggunaan diagram tulang ikan untuk mengetahui akar penyebab cacat prioritas Sablon Plastik sekaligus usulan perbaikannya berdasarkan wawancara dan observasi yang telah dilakukan.

3. Teknik brainstorming dengan beberapa informan internal perusahaan yang terkait dengan permasalahan yang diteliti. Teknik ini dilakukan guna mencari akar penyebab cacat dan memunculkan ide-ide kreatif dari informan terkait untuk penyelesaian atau perbaikan dari permasalahan cacat.

\section{Kualitas di CV. BAYOR PRINT 69}

Berdasarkan wawancara yang dilakukan bersama para karyawan yang bekerja di CV. BAYOR PRINT 69 maka dapat disimpulkan bahwa pada dasarnya kualitas dari produk Sablon Plastik tergolong baik. Hal ini dapat dilihat dari segi tenaga kerja dan sumber daya manusia yang telah berpengalaman selama berpuluh-puluh tahun sehingga telah memahami karakteristik dari produk dan mesin. Hal ini dapat dibuktikan dengan adanya perubahan adaptasi Sablon Plastik yang cepat, yaitu jenis- jenis kantong yang dihasilkan bermacammacam dengan dimensi yang berbeda. Selain itu, meskipun masih menggunakan mesin lama, faktanya mesin-mesin tersebut masih mampu berproduksi dengan baik. Sablon Plastik dapat dikatakan telah baik kualitasnya juga dikarenakan standard pemeriksanaan bahan baku kantong plastic berada diatas standard yang telah ditetapkan oleh perusahaan. Pemeriksaan standard tersebut dilakukan melalui penelitian di Lab Litbang. CV. BAYOR PRINT 69 melakukan pengawasan kualitas menggunakan teknik sampling, yaitu mengambil sampel acak dari kualitas input berupa bahan baku yaitu kantong plastik dan bahan tambahan yang berupa tinta dan lem. CV. BAYOR PRINT 69 menjadikan titik fokus dalam proses pengawasan kualitas yaitu pada saat penerimaan input dengan melakukan uji standard kualitas dari bahan baku dan bahan penolong.

\section{Proses Produksi}

Proses produksi di CV. BAYOR PRINT 69 meliputi input, proses, dan output. Input terdiri dari bahan atau komponen yang meliputi plastik dan cat serta tenaga kerja yang meliputi operator sablon dan tenaga penunjang yang berjumlah satu orang operator sablon. Proses produksi Sablon Plastik dimulai dari Proses Desain, Pencetakan Screen, Set Up Screen, dan Pencetakan Sablon, sedangkan output yang dihasilkan antara lain adalah Plastic Bag, Paper Bag dan lain-lain.

\section{Flowchart}

Flowchart proses produksi Sablon Plastik di CV. BAYOR PRINT 69 digambarkan melalui alur berikut: 




Gambar 1 Flowchart proses produksi sablon

Flowchart dari proses produksi Sablon Plastik di CV. BAYOR PRINT 69 dimulai dari proses mendesain produk yang diinginkan oleh konsumen kemudian dilakukan pencetakan screen sesuai dengan desain yang telah ditentukan. Proses ini dilakukan oleh karyawan dari CV. BAYOR PRINT 69 yang sudah memiliki keahlian khusus dibidang sablon plastik. Sebelum melakukan pencetakan sablon dilakukan set up screen untuk menyesuaikan dengan ukuran plastic sablon. Setelah cetakan sablon terpasang maka kemudian operator akan melakukan penyablonan plastic dengan beberapa kali pengulangan agar menghasilkan hasil yang memuaskan.

Proses penyablonan berlangsung selama 2-3 jam per pc, kemudian hasil penyablonan dikeringkan atau dijemur agar hasil sablon dapat terlihat rapi sehingga terbentuklah kantong plastik yang sesuai dan menarik. Setelah kantong jadi selesai di produksi, kemudian akan dilakukan proses checker, yaitu pengecekan mutu, standard (seperti standard jarak), dan jumlahnya oleh tenaga penunjang yang berada di keluar bottomer. Jika terdapat kantong yang cacat, maka kantong cacat tersebut diletakkan di bagian produk cacat, sedangkan kantong yang baik akan dipacking untuk kemudian dihitung jumlahnya dan dibawa ke gudang penyimpanan.

\section{Analisis Identify Problem}

Pada tahap ini akan digunakan diagram pareto yang berfungsi untuk mengetahui prioritas permasalahan. Berdasarkan data perusahaan yang telah dicantumkan di tabel 1, telah diketahui mengenai jumlah dan jenis cacat yang terjadi selama bulan Januari-Desember tahun 2018. Data tersebut dapat diolah untuk membuat diagram pareto guna mengetahui cacat prioritas yang terjadi. Berikut penyusunan diagram pareto jenis cacat Sablon Plastik CV. BAYOR PRINT 69:

Tabel 2 Data Cacat Sablon Plastik untuk Diagram Pareto

\begin{tabular}{cccc}
\hline $\begin{array}{c}\text { Jenis } \\
\text { Cacat }\end{array}$ & $\begin{array}{c}\text { Jumlah } \\
\text { (pcs) }\end{array}$ & $\begin{array}{c}\text { Presentase } \\
\text { (pcs) }\end{array}$ & $\begin{array}{c}\text { Kumulatif } \\
\text { (\%) }\end{array}$ \\
\hline A1 & 454 & 0,16 & 16,01 \\
A2 & 122 & 0,05 & 20,54 \\
\hline
\end{tabular}

Sumber: Hasil olah data

Berdasarkan tabel tersebut, dapat diketahui bahwa jenis cacat A1 memiliki jumlah cacat terbanyak, yaitu sebanyak 454 Sablon Plastik cacat dengan persentase sebesar $0,16 \%$. Sedangkan cacat A2 memiliki jumlah cacat jauh lebih sedikit, yaitu sebanyak 122 Sablon Plastik cacat, dengan persentase sebesar $0,5 \%$.

Berdasarkan diagram pareto dapat diketahui bahwa kelompok cacat A1 adalah cacat yang menjadi prioritas atau cacat terbanyak. Jenis cacat produk Sablon Plastik yang paling sering terjadi pada kelompok cacat A1 yaitu terdiri dari kantong "mblinded" dan patah (valve) miring.

\section{Diagram Pareto Cacat pada sablon plastik di CV. BAYOR PRINT 69 Periode Januari- Desember tahun 2018}

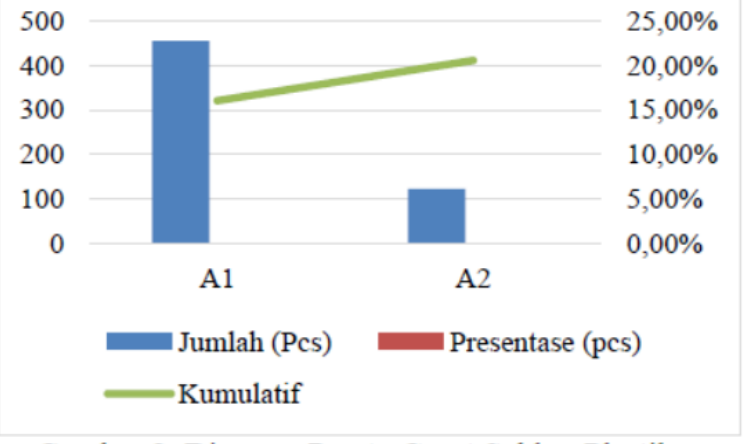

Gambar 2 Diagram Pareto Cacat Sablon Plastik

Novita Yanti Nababan, Achmad Faizal, M. Edgar Jatnika 


\section{Observation at Workstation}

Langkah kedua dalam metode poka yoke adalah observation at workstation, yaitu memilah penyebab di balik masalah cacat produk dengan menggunakan diagram tulang ikan (fishbone diagram) pada permasalahan prioritas. Pada penelitian ini permasalahan prioritas terdapat pada cacat A1, yaitu cacat pada cat yang meleber dan cacat pada A2 yaitu cacat karena plastic yang rusak. Berikut diagram tulang ikan dan penjelasan dari penyebab permasalahan cacat prioritas produk Sablon Plastik.

Berdasarkan diagram tersebut dapat diketahui penyebab cacat pada Sablon Plastik berasal dari faktor material, metode, tenaga kerja, dan mesin yang akan dijelaskan sebagai berikut:

1. Material, material utama yang digunakan adalah plastik, pada saat memilah plastik seringkali terjadi ada plastik yang rusak sehingga plastik tidak dapat di proses ke proses selanjutnya.

2. Metode, cetakan sablon yang gagal seringkali terjadi pada saat proses pencetakan, hal ini desebabkan oleh keterampilan operator sablon untuk mencetak sablon yang dihasilkan.

3. Tenaga Kerja, jumlah produksi yang banyak sering kali membuat operator sablon mengalami kelelahan, sehingga produk yang dihasilkan-pun memungkinkan berdampak kepada kualitas cetakan sablon

4. Mesin, Setup screen merupakan faktor penting untuk menghasilkan hasil cetakan sablon yang baik, oleh karena itu pada proses ini sering kali terjadi kesalahan men-setup screen, karena harus mengandalkan ketelitian untuk melakukannya.

\section{Select Best Idea}

Select best idea berupa pemilihan solusi dari beberapa solusi perbaikan yang terkumpul. Pemilihan solusi terbaik adalah dengan menerapkan ketiga fungsi metode poka yoke, yaitu dimulai dari fungsi warning, control, dan shut down, dikarenakan fungsi tersebut berkesinambungan dan merupakan satu rangkaian di dalam proses produksi, serta usulan perbaikan pada faktor manusia dari yang diambil dari diagram tulang ikan karena faktor manusia tersebut merupakan faktor dominan penyebab cacat. Adapun solusi terbaik tersebut adalah solusi perbaikan yang berdasarkan fungsi metode poka yoke dan faktor manusia dari diagram tulang ikan, menambah operator mesin untuk mengoperasikan mesin dan mendeteksi kesalahan, sehingga jika sinyal dan alarm menyala operator yang bertugas untuk mengoperasikan mesin dan pemberi instruksi titik letak kesalahan menginstruksikan kepada operator mesin baru yang bertanggung jawab untuk mengawasi jalannya proses produksi dan memperbaiki mesin. Operator mesin tambahan ini tentunya juga diimbangi dengan diadakannya pelatihan- pelatihan terkait dengan proses produksi yang dijalankan. Operator mesin tambahan yang diusulkan dapat diambil dari bagian operator mesin sebelumnya dikarenakan operator mesin tersebut tentunya telah mengenali letak-letak kesalahan yang terdeteksi melalui indikator, sedangkan operator mesin yang bertugas untuk mengawasi dan memperbaiki mesin sebaiknya merupakan operator yang fasih dalam hal perbaikan mesin atau dapat diambil dari bagian pemeliharaan. Hal ini diharapkan dapat menciptakan efisiensi waktu dan efektifitas proses produksi.

\section{KESIMPULAN DAN SARAN}

Berdasarkan pembahasan di atas maka dapat ditemukan kesimpulan sebagai berikut (1) Kualitas Sablon Plastik di CV. BAYOR PRINT 69 tergolong baik. (2) Proses produksi Sablon Plastik dimulai dari proses desain kantong plastic, pencetakan screen, set up screen, dan pencetakan sablon hingga menjadi kantong jadi kemudian dilakukan checker dan penyimpanan kantong jadi. (3) Terdapat dua kelompok cacat Sablon Plastik, yaitu cacat A1 dan cacat A2. Jenis cacat A1 yang paling sering terjadi adalah cacat karena cat yang meleber, sedangkan pada cacat A2 yang paling sering adalah cacat karena kantong plastik yang rusak. Namun, berdasarkan pareto chart, cacat terbanyak adalah kelompok cacat A1.

Usulan perbaikan yang dapat diberikan dengan menggunakan metode poka yoke adalah dengan menggunakan ketiga fungsi dari metode poka yoke, yaitu pemberian alarm pada saat terjadi kesalahan dan pemberian sensor agar mesin berjalan perlahan saat terjadi kesalahan merupakan fungsi warning, melakukan pengecekan dan perbaikan sampai tidak terjadi kesalahan merupakan proses control, dan mematikan mesin saat terjadi kesalahan besar atau mesin mengalami trouble parah. Selain itu, dengan menambah operator mesin khusus untuk mengoperasikan mesin dan berjaga-jaga jika ada

Novita Yanti Nababan, Achmad Faizal, M. Edgar Jatnika 
kesalahan yang terdeteksi dapat dijadikan usulan dari peneliti.

Saran yang dapat diberikan oleh penulis adalah Setiap jenis kecacatan seharusnya tidak digabung atau dikelompokkan, namun akan lebih baik jika jenis kecacatan tersebut disortir satu per satu agar nantinya dapat lebih mudah pada proses perbaikan kecacatan tersebut, sehingga cacat yang terjadi satu per satu akan dapat diatasi dan proses produksi dapat berjalan lancar tanpa adanya cacat. Pelaksanaan pelatihan perbaikan mesin bagi operator mesin dan tenaga penunjang, sehingga saat terjadi kesalahan pada mesin pada saat proses berlangsung, operator mesin dan Tenaga penunjang dapat memperbaikinya tanpa harus menggantungkan perbaikan mesin kepada bagian pemeliharaan sehingga akan lebih menghemat waktu dan tidak ada waktu yang terbuang akibat menunggu bagian pemeliharaan untuk memperbaikinya.

\section{REFERENSI}

Arnas, E.R, de Sousa Jabbour, A.B.L., \& Saltorato, P. (2013). Relationships Between Operations Strategy and Lean Manufacturing: An Exploratory Study. African Journal of Business Management, 7(5), 344-353.

Assauri, Sofjan. (2016). Manajemen Operasi Produksi. Jakarta: PT .Raja Grafido Persada.

Dudek-Burlikowska, M \& Szewieczek, D. (2009). The Poka-Yoke Method as an Improving Quality Tool of Operations in The Process. Journal of Achievements in Materials and Manufacturing Engineering, 36(1), 95-102.

Gaspersz, Vincent \& Fontana, A. (2011). Malcolm Baldrige Criteria for Performance Excellence. Bogor: Vinchristo Publication.

Gaspersz, Vincent. (2007). Lean Six Sigma for Manufacturing and Service Industries, Jakarta: PT. Gramedia Pustaka Utama.

Haming, Murdifin dan Mahfud Nurnajamuddin. (2014). Manajemen Produksi Modern, Operasi Manufaktur dan Jasa. Jakarta: Bumi Aksara.

Heizer, Jay \& Barry Rander. (2015). Manajemen Operasi: Manajemen

Keberlangsungan dan Rantai Pasokan (Edisi 11). Jakarta: Salemba Empat.
Khoirunnisa \& Gerry Ganika. (2016). Analisis Kecacatan Produk Sebagai Upaya Perbaikan Kualitas Menuju Zero Defect (Studi pada Produk Pipa Spiral ASTM A252 Produksi PT. KHI Pipe Indisties Cilegon, Banten). Jurnal Manajemen dan Bisnis, 9(1), 121-136.

Khrisnan, Chinmaya. (2015). Zero Defect Management - A Study on The Relevance In Modern Days. International Research Journal of Engineering and Technology (IRJET), 2(5), 578-582.

Kumar, Rajan et al,. (2016). Poka-Yoke Technique, Methodology, \& Design. Indian Journal of Engineering, 13(33), 362-370.

Moleong, Lexy J. (2013). Metode Penelitian Kualitatif. Edisi Revisi. Bandung: PT. Remaja Rosdakarya.

Zulian, Yamit. (2013). Manajemen Kualitas Produk \& Jasa. Yogyakarta: Ekonisia.

Novita Yanti Nababan, Achmad Faizal, M. Edgar Jatnika 